\title{
FUTURE SCENARIOS OF EUROPEAN FORESTS
}

\author{
GERT-JAN NABUURS \\ Wageningen Environmental Research, WUR, Netherlands, \\ e-mail: gert-jan.nabuurs@wur.nl
}

Received: $24^{\text {th }}$ October 2018, Accepted: $23^{\text {th }}$ January 2019

\begin{abstract}
Scenarios based on contrasting storylines can be used as a tool to explore the different ways in which the future may develop and their impacts on the sustainability of European forestry. These scenarios are neither predictions nor forecasts, but are used to create a consistent image of a future, and to help decision makers and other actors in making well informed choices. Each storyline assumes a distinctly different direction for future developments. Here we discuss characteristics of scenario studies forest large scale forest resources in general and focus on a few recent trends and their long term impact on European forests, as e.g. nature oriented management, carbon credits, and extra demand for bioenergy.
\end{abstract}

Keywords: European forests, carbon sequestration, multifunctionality, bioenergy

\section{INTRODUCTION}

European forests cover $36 \%$ of the European land area and they fulfil a multitude of functions; from wood production to nature conservation, climate mitigation, water protection, etc. It's this multitude of functions that is achieved by a huge variety of forest owners and national legislations that make these forests unique in the world. Europe namely went through a centuries long period of deforestation and degradation which already started before the Roman Era. Then in Medieval times, wood became a scarce raw material in many regions, resulting in the first ideas of a sustainably managed forest as published by Von Carlowitz (1713). This has resulted in many new plantings and also after WWII large scale restoration and afforestation took place in a time when resources were needed. This has yielded us the present day vast area of forest, still increasing in area and amount of wood per hectare.

Until quite recently, forests and forest policy have been regarded as a sovereign issue in Europe, with few international measures. This diversity also led to fragmentation in research, and a concentration on national, ecological and silvicultural aspects. Maybe since the acid rain era in the late eighties however, we stand for ever larger and more complex forest-related issues that are cross sectoral and require a multi-national effort. E.g. climate change and the trends towards a bioeconomy are the more recent ones. Only with this multi-national and interdisciplinary effort the required innovation in forest and forest products research can take place. Scenario studies are one way of gaining insight in alternative futures of European forests under these recent trends and demands. 
Fig. 1: Forest tree species map for European forests.

The EU27 countries cover some 178 million ha; Europe's main form of land use. Source: Brus et al. 2011.

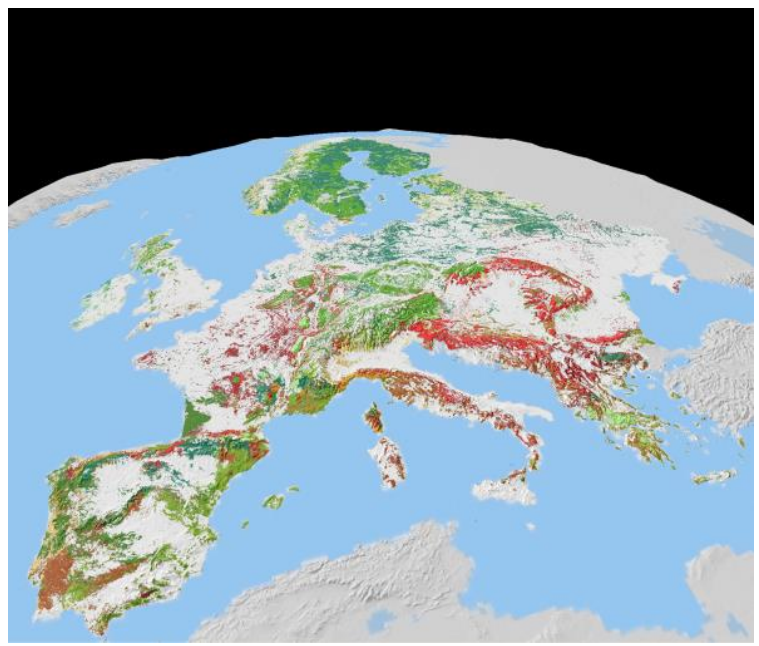

\section{CHARACTERISTICS OF SCENARIO STUDIES IN GENERAL}

By 2050 the world will have changed in ways that are difficult to imagine - as difficult as it would have been at the end of the $19^{\text {th }}$ century to imagine the changes of the following 100 years. Scenarios that are based on contrasting storylines can be used as a tool to explore the different ways in which the future may develop and their impacts on the sustainability of European forestry.

These scenarios are neither predictions nor forecasts, but are used to create a consistent image of a future, and to help decision makers and other actors make well informed choices (Arets et al., 2008). Each storyline assumes a distinctly different direction for future developments, and does not necessarily aim to be realistic. Conclusions should not be drawn from these storylines.

A set of scenarios aims to describe divergent futures that encompass a significant portion of the underlying uncertainties in the main driving forces. These drivers cover a wide range of key characteristics such as demographic change, economic development, and technological change. For this reason, their plausibility or feasibility should not be considered solely on the basis of an extrapolation of current economic, technological, and social trends.

Reference futures (a baseline) and policy scenarios should be separated. Reference futures are 'benchmark' scenarios with dynamics, but without major policy interventions. Then subsequent comparison with policy scenarios enables the assessment of the effect certain policies will have (Alcamo, 2001).

In 1996 the IPCC decided to develop a new set of emission scenarios that are described in the Special Report on Emission Scenarios (SRES) (IPCC, 1997). This set of scenarios is now known as the SRES scenarios, which were used by the IPCC for their third and fourth assessments. More recent these scenarios were updated and labelled 'Representative Concentration Pathways' (RCPs). The scenarios are mostly developed for energy system parameters and related emissions. The underlying 4 reference futures, however, provide 
consistent storylines on the development of drivers like population growth and economic development in the future.

\section{DEVELOPMENTS IN THE MULTI SECTORAL SURROUNDINGS}

Forests have to play their role in mitigating climate change, in providing biomass for bio energy, in providing jobs and opportunities in the rural areas of Europe, i.e., playing their role in the green economy. Furthermore, the vast land covered with forest needs to be managed sustainably and to protect soils and water, provide space for tourism, sequester carbon, and protect biodiversity. All this, under the impacts of climate change.

To meet these needs, changes in governance, institutions, and research structure need to take place in order to be much more innovative along the whole chain from genetics, to forest management, to harvesting, and via a variety of products, back to recycling. Also, the multi sectoral and integrated aspects need to stand out much more in research. Only then, the sustainability in all its aspects can be guaranteed.

\section{Fig. 2: Total damage due to disturbances in Europe.}

Insight in future development of these disturbances will help decision makers make necessary choices. Source: Schelhaas et al., 2008

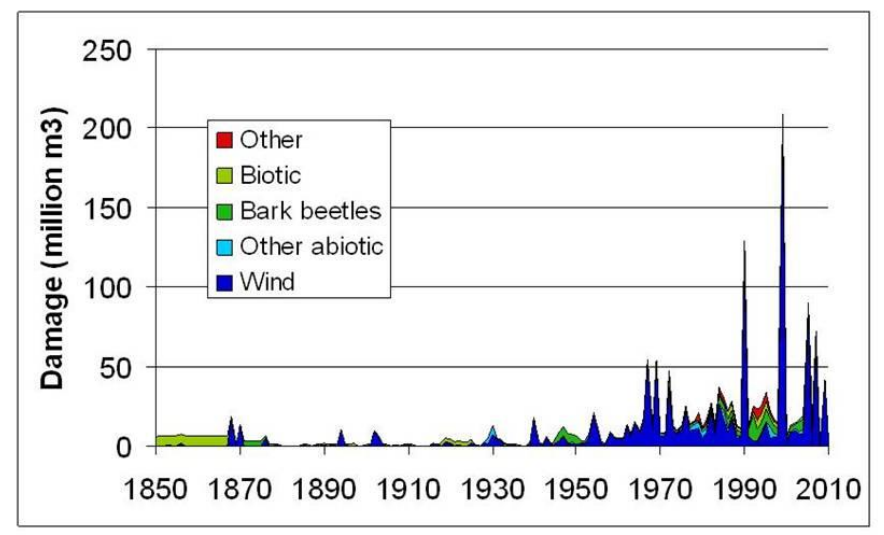

At the international policy level, forest policy has moved to an international level in Europe with ups and downs. In June 2011, Ministers responsible for forests met in Oslo at the FOREST EUROPE Ministerial Conference on the Protection of Forests in Europe. They made the far-reaching decision to launch negotiations for a Legally Binding Agreement on Forests in Europe. This has been a first step towards pan European forest legislation, but it was eventually stalled in 2016. Also the EU forest strategy is being revised. Maybe through these international policy measures, developments as the economic crisis can be turned into a break point for new developments of the forest sector.

The financial crisis which developed in autumn 2008 and the subsequent economic consequences namely have led to a fundamental shift within forestry and the forest industry sectors, the effects of which are being felt through the entire chain from forest to markets. Never, since the oil crisis in the 1970s, have the forest products markets experienced such a downturn. In response, some countries have implemented economic stimulus packages to tackle the crisis and to promote a move towards a greener economy. 
Recently, attention has shifted towards economic objectives and the green economy: The wood and forestry sectors can make a significant contribution towards meeting green economy objectives, linked to climate change policies, mainly through the abatement of greenhouse gas emissions and expansion of renewable energy objectives. There are several main routes by which the wood and forestry sectors can contribute. These are sustainable wood consumption including certification and green buildings, a low carbon forest sector, creating green jobs, valuation of ecosystem services, and improved governance of the forest sector. Through this combined set of measures stimulated by government measures, and supported by research, the forest sector can really make its contribution.

\section{EXAMPLES OF SCENARIO STUDIES}

Here, we touch upon some examples of scenario studies, and the tool by which they can be carried out. Scenario studies can be carried out in a multitude of ways, but in the last decades they are more and more carried out with computerized models, aided by a fast increase in synchronised data, at ever higher level of detail. These computerized models span a wide variety, from multi sectoral global integrated models as, e.g., IMAGE (Alcamo et al., 1998), and EURURALIS (http://www.eururalis.eu, Helming et al., 2010) to specific forest sector market models and to European forest resource models. The European Forest Information SCENario model (EFISCEN; (Sallnäs, 1990; Schelhaas et al., 2007; Nabuurs et al., 2006) is a large-scale forest scenario model that projects forest resource development on regional to European scale (Eggers et al., 2008). Here we look into three scenarios as developed for European forests (see for further details Nabuurs et al., 2006).

\section{NATURE ORIENTED MANAGEMENT (NOM)}

It was assumed that NOM is going to be important for European forestry in the future and will reduce a forest owner's willingness to supply, i.e., as a result of less dependency of the forest owner's income on the forest, and the valuation of other functions the average owner is assumed to supply less at the same stumpage prices. This reduction in supply willingness is incorporated for the 27 European countries as a combination of the following assumptions:

- longer rotations (20 years for long rotations, and 10 years for short rotation species $(<60$ years)). This was kept rather simple because of a lack of detailed information on how the management of each tree species may change under NOM;

- from total fellings an additional $10 \%$ must originate from thinnings/group fellings;

- thinning can only be carried out in forests with growing stocks over 150 to $300 \mathrm{~m}^{3} / \mathrm{ha}$, depending on the forest type. This is based on the assumption that non-commercial thinnings are not being practised anymore;

- a species change towards the more natural/indigenous species is incorporated as a 30 to $40 \%$ chance that species like spruce and pine will be regenerated with species like beech and oak. The accompanying assumption is that sufficient sites are available where this is a logical step;

- $\quad$ set aside from harvesting all beech and oak forests older than 150 years. Initially, this usually affects 1 to $1.5 \%$ of the total forest area in a country. Due to ageing of the forest during simulation, this area may increase to some 6-10\% by 2060 depending on management regimes, felling levels, etc. These forest areas remain part of the simulation, but are simply not affected by harvesting anymore. 


\section{CARBON CREDITS}

\section{Amount of new areas being planted due to climate policies}

Changes in forest areas are already taking place at the moment without any carbon credits being paid. The average annual net changes in the forest area during the period 1983-1993 were highest in France and Spain with, respectively, 61.6 and 86 thousand hectares annually. Belgium, Serbia \& Montenegro and Albania had seen an overall decrease in forest area ${ }^{1}$. However, these are the net changes between the gross increases and decreases in forest available for wood supply (FAWS) and forest not available for wood supply (FNAWS). For the 27 countries under study, an average annual increase in FNAWS of 324,200 ha and in FAWS of 103,600 ha has been reported. Thus, there is an overall increase in forest area of some $0.3 \%$ but only part of it is available for wood supply.

It was assumed that climate policies and bioeconomy trends will stimulate the gross FAWS area expansion: from the current $+103,000$ ha per year to 290,000 ha per year (on average over the whole simulation period). This scenario assumption will increase the total forest available for wood supply in the 27 European countries from the present 134 million ha (in our database) to 150 million ha. This increase was assumed to take place mainly between 2010 and 2040 and to apply to the present forest area per country with some emphasis on pre-accession countries.

\section{Measures in existing forests}

Additional carbon credits may be gained in the future from 'forest management' up to the maximum amount which is capped under the LULUCF regulation (EU 2018). As it is in line with a strong trend in forestry, owners may be interested in it, provided that it is paid for. Taking all this into consideration, as well as taking into account the high uncertainty level in outcomes of future international climate negotiations, it would be fair to assume that this may lead to a prolongation of rotation lengths by 10 years (irrespective of country or site).

\section{BIO-ENERGY}

In the EU renewable Energy Directive (EU, 2016) the EU aims at a contribution of Renewable Energy Sources (RES) up to $27 \%$ 2030. The European Commission has designated biomass as an important Renewable Energy Source on top of the current consumption of roundwood and industrial residues of approximately 40 million $\mathrm{m}^{3} \mathrm{y}^{-1}$ in EU and EFTA countries. In 2005, the European Commission published a Biomass Action Plan (EC, 2005b), followed by a communication on an EU Strategy for Biofuels (EC, 2006). The Biomass Action Plan aims to increase biomass use to 150 Million tonne oil equivalents (in primary energy terms) in 2010 or soon after.

Due to the above mentioned RES policy, an increase in demand for wood fibres from forest resources for the production of bio-energy has already been recorded and it can be expected to increase further. The increased demand for roundwood, based on the EU Whitepaper, has been calculated to amount to approximately 92 million $\mathrm{m}^{3}$ by 2010. Later, Lindner for EEA (2006) assessed an availability of environmentally compatible biomass from forestry of around 39 million tonne oil equivalent ( $\sim 200$ million $\mathrm{m}^{3}$ from both stemwood and branches).

From the current state of implementation of the RES policy in Europe, it can be concluded that it is unlikely that the RES targets for woody biomass will be met within the intended time

\footnotetext{
1 This is not completely true anymore according to updated TBFRA data as published by UNECE/MCPFE's State of Europe's Forests, 2003.
} 
span. Adjustment of the time span or of the quantitative targets seem inevitable. An extra felling of 80 million $\mathrm{m}^{3}$ of roundwood by 2025-2030, matches this requirement and is incorporated as an assumption in the 'new management trends' scenario. This additional fellings is distributed over the countries of study with respect to their current share in total fellings.

Combining all these trends mentioned above is called the new management trends scenario. Not applying these trends is called the 'projection of historical management' still with increased demand, stable demand is called 'benchmark'.

\section{RESULTS}

Foremost, the results show that a large increase in supply can be achieved sustainably in European forests. The supply under 'new management trends' increased from 409 million $\mathrm{m}^{3}$ $\mathrm{y}^{-1}$ in 2005 to 647 million $\mathrm{m}^{3} \mathrm{y}^{-1}$ in 2060 . Under the projection of historical management, the supply increased to 729 million $\mathrm{m}^{3} \mathrm{y}^{-1}$ in 2060 (Fig. 3). So, despite an 80 million $\mathrm{m}^{3}$ higher demand, the new management trends give a reduction in actual fellings of 82 million $\mathrm{m}^{3}$. Thus, in total a reduced supply or shortage of 162 million $\mathrm{m}^{3} \mathrm{y}^{-1}$ was found despite an increase in forest area of 16 million ha over a time period of 55 years in the new management trends scenario. When keeping the felling level very stable (Benchmark), the average growing stock rises from 188 to $287 \mathrm{~m}^{3} \mathrm{ha}^{-1}$. Higher rates of mortality were found under these growing stocks.

Fig. 3: Actual supply under the various scenarios (Nabuurs et al., 2006).

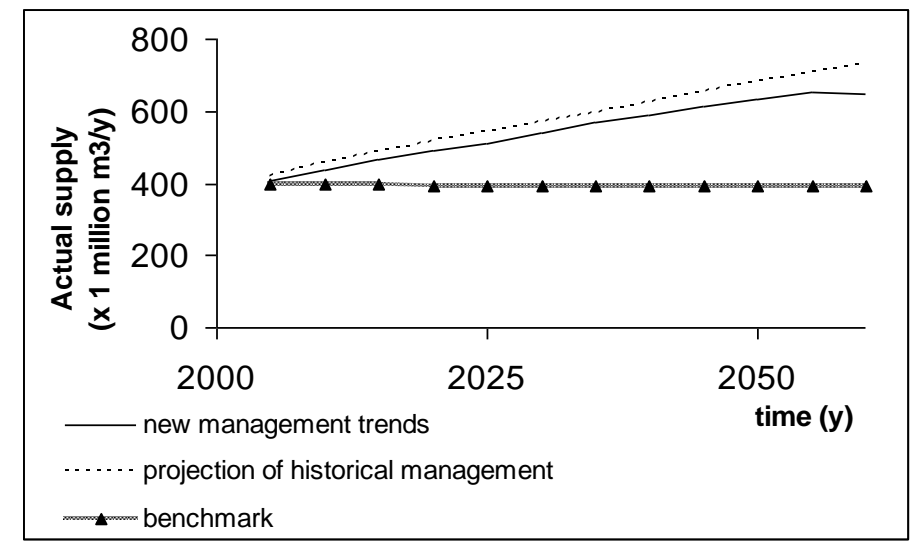

The high supply levels were found within European forests, because we allow temporarily overharvesting in comparison to increment (Fig. 4). Overharvesting occurs more severely in the 'projection of historical management' scenario. Still the average growing stock increases in this scenario. In all regions where overharvesting occurs (usually starting in 2040), this happens often with an increasing linear trend in time. This in contrast to the "new management scenario', where overharvesting is severe in some regions in 2030 and 2040, but then declines again in 2050 because of the constraints taking effect, i.e., the available stock is used up in a certain decade. 
Fig. 4: Felling over increment ratio in the new management trend scenario (Nabuurs et al., 2006)
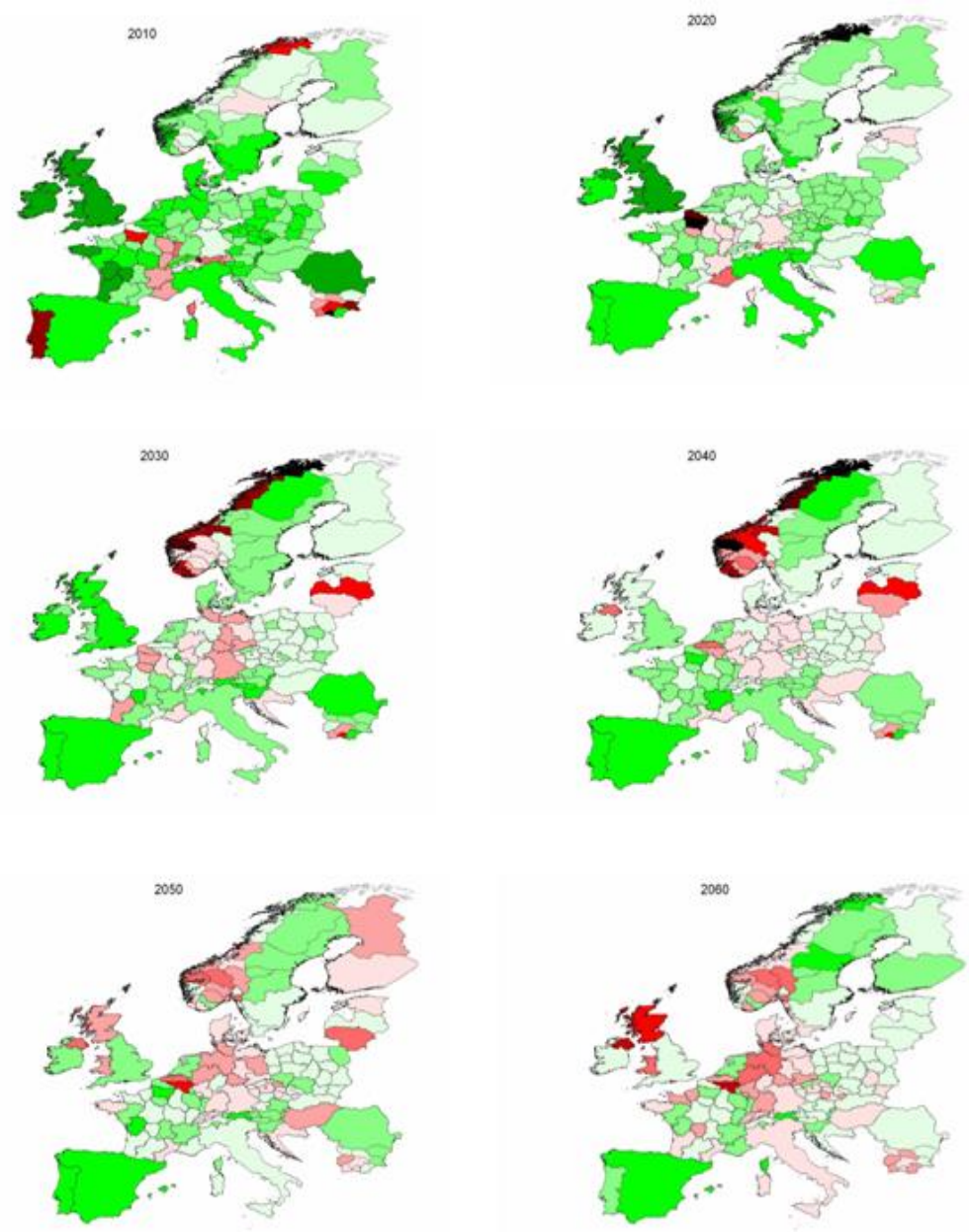

\begin{tabular}{|l|l|}
\hline Harvest_Increment \\
Ratio (\%) \\
$1-20$ \\
$20-40$ \\
$40-60$ \\
$60-80$ \\
$80-100$ \\
$100-120$ \\
$120-140$ \\
$140-160$ \\
$160-180$ \\
$180-200$ \\
$200-220$ \\
$220-240$ \\
\hline$>240$ \\
\hline$\square$
\end{tabular}


In the new management trends scenario we quantified the large scale effect of management constraints. It becomes clear that effects of management changes like setting aside forests for nature reserves, tree species changes, and rotation prolongation have their influence on total fellings mainly in the long term (Fig 3). Namely only after 2050 the fellings, as achieved under 'new management trends', start to decline. Without the afforestations the decline in fellings would have been stronger, but still the afforestations did not fully compensate for the effect of the constraints.

When keeping the felling level stable (Benchmark), the average growing stock rises strongest from 188 to $287 \mathrm{~m}^{3} \mathrm{ha}^{-1}$. The age class distributions (Fig 5) also show a combination of effects of different measures. Although the aim of the "new management trends' scenario was to enhance biodiversity by creating more old forests, this is only partly achieved.

Fig. 5: Age class distribution in 2000 and in 2060 of all European forests under simulation in the benchmark (top) and the new management trends scenario (bottom) (Nabuurs et al. 2006).
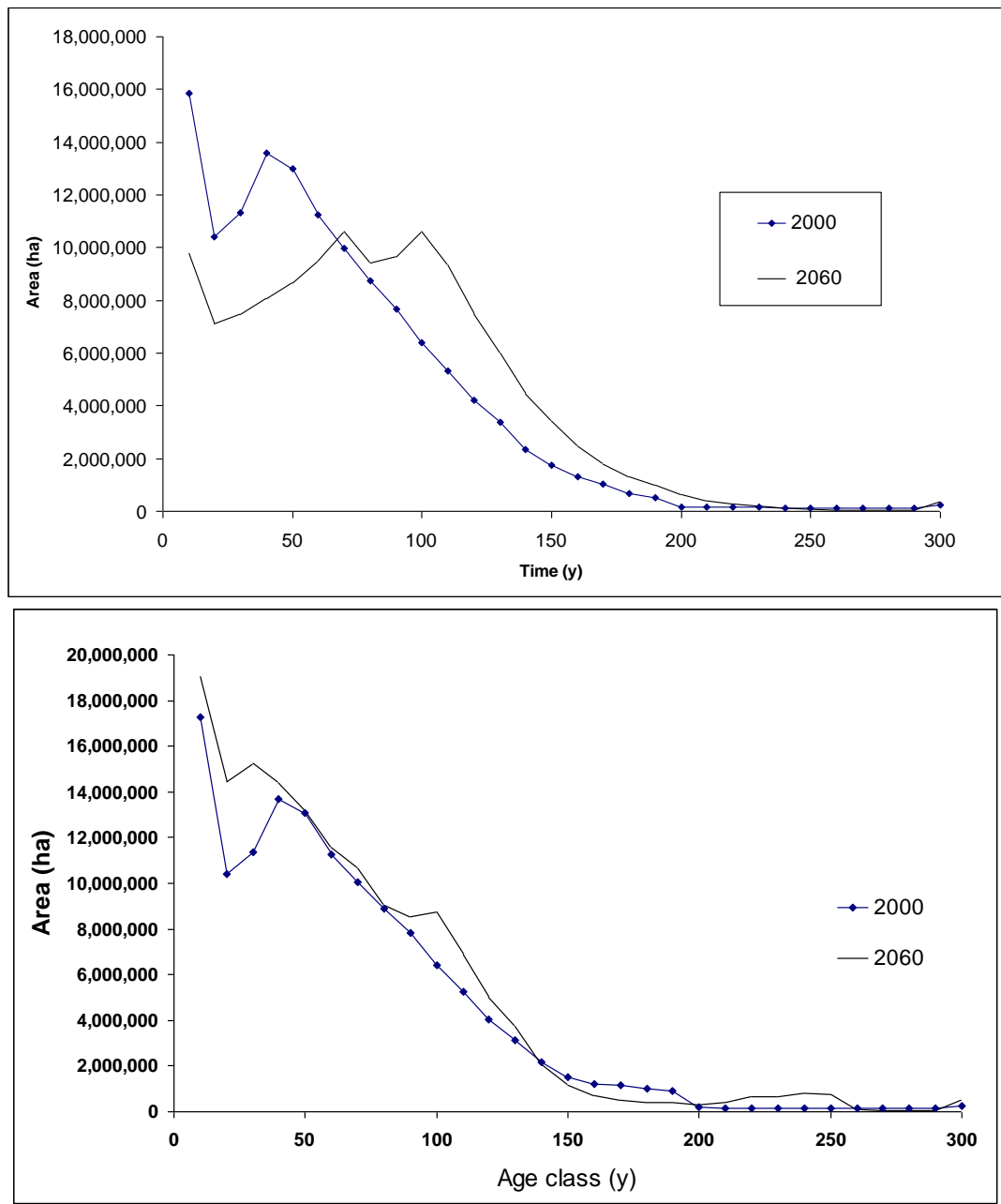
We can see in Figure 5 (bottom) that the area of forests older than 200 years has increased from 1.7 million ha in 2000 to 4.4 million ha in 2060. However, the average age has hardly increased because in this scenario we also try to increase fellings a lot in combination with prolongated rotations. This leads to more forest area in 2060 in the age classes 100 to 150 , but leads to less forest area in the classes $150-200$. That is, prolongating a rotation means that you have to find the same amount of wood, but in the older age classes! Figure 5 (top) shows, for the benchmark scenario (with simply a stable and rather low amount of fellings), that the ageing of the forest is much more pronounced in this case in the classes 80-200 years.

\section{CONCLUDing}

Models and scenario analysis can provide a very powerful tool for explorative studies, provided they use reliable input data and are based on thorough understanding of ecosystem functioning as well as of needs and demands from society under a rapidly changing ecological setting (Hanewinkel et al., 2012). Large-scale scenario models in combination with land cover data provide a means for upscaling and expansion of stand-based approaches and can be used to explore policy options and to show consequences of different management objectives. The usefulness of the results of such studies in a decision-making context depends as much on the quality of the research design as on the communication and dissemination of results to the stakeholders and decision-makers involved, whereby it should be made clear that results from scenario studies should not be viewed as blueprints for future developments, but rather as explorations of possible futures.

\section{REFERENCES}

Alcamo, J. (2001). Scenarios as tools for international environmental assessments. Experts' corner report, Prospects and Scenarios No 5. Environmental issue report No 24, European Environment Agency, Copenhagen, Denmark.

Alcamo, J., R. Leemans and E. Kreileman (eds) (1998). Global change scenarios of the 21st century. Results from the IMAGE 2.1 model. Pergamon \& Elseviers Science, London. pp 296.

Arets, E., T. Palosuo, A. Moiseev, G.J. Nabuurs, D. Slimani, C. Olsmat, J. Laurijssen, B. Mason, D. McGowan, D. Vötter. (2008). D 1.4.7. Reference futures and Scenarios for the European FWC. Eforwood deliverable to Brussels. 32p.

Brus, D.J., G.M. Hengeveld, D.J.J. Walvoort, P.W. Goedhart, A.H. Heidema, G.J. Nabuurs, K. Gunia. (2011). Statistical mapping of tree species over Europe. European Journal of Forest Research. 131: 145-157

European Commission (2005). Communication from the European Commission on the Biomass Action Plan, COM(2005)628

European Commission (2006). Communication from the European Commission on An EU Strategy for Biofuels, COM(2006)3

EU (2016). Proposal for a DIRECTIVE OF THE EUROPEAN PARLIAMENT AND OF THE COUNCIL on the promotion of the use of energy from renewable sources (recast). $\operatorname{COM}(2016) 767$ final/2

EU (2018). Regulation (EU) 2018/841 of the European parliament and of the council of 30 May 2018 on the inclusion of greenhouse gas emissions and removals from land use, land 
use change and forestry in the 2030 climate and energy framework, and amending Regulation (EU) No 525/2013 and Decision No 529/2013/EU. Official Journal of the European Union 19 June 2018, L 156/1-25. 2018.

Eggers, J., M Lindner, S Zudin, S. Zaehle, and J Liski (2008). Impact of changing wood demand, climate and land use on European forest resources and carbon stocks during the 21st century. Global Change Biology 14: 1-18

Hanewinkel, M., D.A. Cullmann, M.J. Schelhaas, G.J. Nabuurs, N.E. Zimmermann. (2012). Climate change may cause severe loss in economic value of European forestland. Nature Climate Change 3: 203-207. DOI: 10.1038/NCLIMATE1687

Helming, J.F.M., Janssen, S., Meijl, van, H., en Tabeau. A., (2010). Impact assessment of post 2013 CAP measures on European agriculture. LEI report 2010/085. The Hague.

IPCC (2000). Special report on emission scenario. IPCC. Cambridge University Press. 599 p.

Nabuurs, G.J., J. van Brusselen, A Pussinen. M.J. Schelhaas. (2006). Future harvesting pressure on European forests. European Journal of Forest Research. 126: 391-400

Sallnäs, O., (1990). A matrix growth model of the Swedish forest. Studia Forestalia Suecica 183. Uppsala, Swedish University of Agricultural Sciences, Faculty of Forestry, 23 pp.

Schelhaas, M.J., J Eggers, M Lindner, G.J. Nabuurs, A Pussinen, R Paivinen, A Schuck, P.J Verkerk, D.C. van der Werf and S Zudin. (2007). Model documentation for the European Forest Information Scenario Model (EFISCEN 3.1.3). Alterra Report 1559. 118 p.

Schelhaas, M.J., (2008a). Impacts of natural disturbances on the development of European forest resources: application of model approaches from tree and stand levels to large-scale scenarios. Dissertationes Forestales 56, Alterra Scientific Contributions 23.

Von Carlowitz, (1713). Sylvicultura oeconomica.

UN ECE/ FAO (2011). The European Forest sector Outlook. Study II 2010-2030. ECE/TIM/SP8. Geneva. 111 p. 